\title{
From Horror to Humour: Tracing Parody in Joseph Heller's Catch-22
}

\author{
María del Pilar Berruete Rodríguez \\ Universidad de Zaragoza
}

\begin{abstract}
I understand here under parody only such literary products that formally imitate in toto or in part a known text, or secondarily appearances, manners and customs, events and persons. This imitation is seemingly accurate, but in fact distorted, with conscious and recognizable humor (Lehmann 3)
\end{abstract}

Leading on from this notion of parody as "a distorted imitation of a known text with conscious and recognizable humour" and also the one given by Linda Hutcheon in A Poetics of Postmodernism ("repetition with difference, not necessarily comic"), this paper is going to deal with the analysis of parody firstly regarding previous war American novels, secondly as represented by Yossarian, the protagonist of Heller's Catch-22 (1961), thirdly in the story of the novel ("the romance quest") and finally in relation to Ernest Hemingway's A Farewell to Arms (1929).

Throughout the paper I will show how the traditional novel is transformed through the use of parody, the burlesque and language. All these elements create a perfect atmosphere for the creation of a novel which has been described as absurdist for its use of an absurdist theme and also of absurdist techniques, including it in the trend of absurdist writers from the 1960s in America.

As a consequence of my analysis, it will be shown that what is apparently a comic novel, with the constant use of the so-called black humour, is in fact a very serious protest against the powerful and bureaucratic institutions, especially the military forces, which deprive individuals of their own identity. Thus, although readers might find themselves smiling or laughing while reading the novel, they must take into account that the message is quite serious. However, the ending of the novel is not overtly pessimistic, even optimistic (as I will discuss later on), because after all there is some way to escape the inner circle of Catch-22.

In the end, I will conclude with the idea that Heller's novel shows how Yossarian becomes aware of the power of humans to produce symbols "ad infinitum" and also of the absurd lack of meaning in daily life. These and other traits of the novel could lead to consider Catch-22 as a post-modernist novel. In fact, Heller himself struggles against the stiff limits of language, systems and codes, and parody becomes metafictional since there is self-reflexiveness: Heller becomes a mirror of Yossarian fighting against the absurd norms in Catch-22. 
First of all, Heller's Catch-22 can be regarded as a parody of previous war narratives written before and after the 1920s, such as The Last of the Mohicans (by J. Fenimore Cooper, in 1826), The Red Badge of Courage (by Stephen Crane, in 1894), Three Soldiers (by John Dos Passos, in 1921) or A Farewell to Arms (by Ernest Hemingway, in 1929). These novels dealt with the facts of war directly or else with its deep consequences and their authors depicted the life of the troops in the trenches as a result of their own experience in the war. These novels described the horrors of war and also its folly, since the enemy was also found on one's own side. Unlike traditional war novels, Catch-22 ironises in its presentation of war as something paradoxically positive and lucky, as a "way out,"1 as Doc Daneeka and his helpers see it:

Fortunately, just when things were blackest, the war broke out. (50)

Nothing so wonderful as war had ever happened to them before; and they were afraid it might never happen to them again. (180)

In addition, the "positive" aspects of war, such as comradeship and the development of weaponry, are continuously parodied in the book. On the one hand, Yossarian has no friends, except for Dunbar and maybe Doc Daneeka. He has just acquaintances and although he is surrounded by people, there is not any effectual communication because language has become illogical. On the other hand, the advanced technical war equipment is substituted for trade items, as in the case of McWatt's bedsheet, used for Milo's purposes or when Yossarian's B-25 turns out to have a tight crawlway to escape through it.

In fact, Malcolm Bradbury described Catch-22 as "an anti-war novel about World War II as a grotesque and absurd fantasy" that represents "contemporary America." For Bradbury, history became fictional in the 1960s to subvert it. As a result, there was a fantastic world of facts and a new hyper-realism towards reportage and fictionality, away from realism. Black humour appeared to explore the absurdity of contemporary society and of the rational responses to it. This new fiction was prone then to parody, irony and metafiction, as a way to challenge meaning. In addition to this, Catch-22 was turned into a film by Paramount Pictures in 1970 and it was also described as an anti-war satire of epic proportions.

Some critics have pointed out that Catch-22 is a war novel but that war is not its true subject. Thus, Tonny Tanner wrote that it was "less about the tactical struggle of two armies than the struggle for survival of the individual within his own society" (72). Then for Tanner, Yossarian is a hero not of war but of society since he manages to escape the stiff military organisation of parades and so on. Tanner sees the characters as cartoon-strip grotesque personages ${ }^{2}$ and there is black humour because Yossarian becomes "a manipulable and disposable thing" (74). Following Tanner, A. Hilfer claims that "the Second World War is the setting of Catch-22, but not its true subject. . . . The Cold War and the political

\footnotetext{
${ }^{1}$ The mode of the novels written after World War II in America, like Catch-22, changed mainly because of some great events happened between 1940 and 1970, such as the passing from the concept of "hero" to that of "victim" or the self-questioning of a triumphant country after Vietnam or the 1960s upheavals.

${ }^{2}$ According to Charles B. Harris, the use of caricature shows rejection of the realistic characterization's belief that human beings can be accurately formulated (27).
} 
situation of the 1950s is more to the point than the Second World War" (114). This analysis coincides with Joseph Heller's apparent intentions of writing about "the contemporary regimented business society depicted against the background of universal sorrow and inevitable death that is the lot of all of us" (114).

Secondly, the figure of Yossarian can be regarded as a parody of the war hero because he is not a hero of war but of a stiff contemporary society. As a matter of fact, for Hilfer, Yossarian is a 1960s hero because he is aware of the absurd logic of that war and not because of his humanism. Besides, Malcolm Bradbury, in his Introduction to Joseph Heller's Catch-22, saw Catch-22 as a satire on war but also as a story about the Cold War and capitalism.

It can be argued, therefore, that Yossarian becomes a non-heroic protagonist as he acts as a parodic "hero" of war. This idea reinforces the vision of the novel as a parody of previous war narratives, since Catch-22 presents an image of war which is very different from that shown in American war literature like Fenimore Cooper's The Last of the Mohicans, Crane's The Red Badge of Courage or Hemingway's A Farewell to Arms.

Yossarian is a weak existential character to stand a war and from the very beginning of the book he tries to avoid flying, pretending to be ill with a liver ailment in order to stay more at hospital. He is not a self-confident man and he is confused about his own identity. Not surprisingly, he thinks that war provides him with a heroic mask and he plays with different names acting as censoring officer, such as "Washington Irving" or "John Milton." He tries to look for his own self and becomes an usurper of identities. ${ }^{3}$ This is seen more clearly when at hospital, he follows Dunbar, who "liked pulling his rank" and who "was not Dunbar any more but Second Lieutenant Anthony F. Fortiori” (361):

The startled patient jumped down to the floor at Yossarian's command and ran away. Yossarian climbed up into his bed and became Warrant Officer Homer Lumley, who felt like vomiting and was covered suddenly with a clammy sweat. He slept for an hour and wanted to be Yossarian again. It did not mean so much to have a father in the state legislature and a sister who was engaged to a champion skier. (361-362)

In addition, he identifies himself with characters who are mythical or fictitious, such as Tarzan, Mandrake, Flash Gordon, Bill Shakespeare, Cain, Ulysses or Lot in Sodom. There are also more examples when Yossarian takes someone else's personality, as when he tries to imitate a soldier who saw everything twice or when Doc Daneeka asks him to be an Italian man who has just died and whose family has come to visit him. In the end, Yossarian's indefinition and weakness leads him to be a puppet in the hands of an absurd military organisation ruled by the linguistic trap denominated "catch-22," which deceives men increasing the flying missions constantly and avoiding their escaping the war. The culmination of this loss of identity takes place when Yossarian is wounded in his leg and then the nightmare of non-identity, announced previously with the soldier in white, becomes real:

\footnotetext{
${ }^{3}$ Role playing, masked identities or impersonation become favourite motifs in the novels written by some of the most celebrated postmodern American writers of the 1960s, such as John Barth or Thomas Pynchon. The issue has obvious existentialist roots.
} 


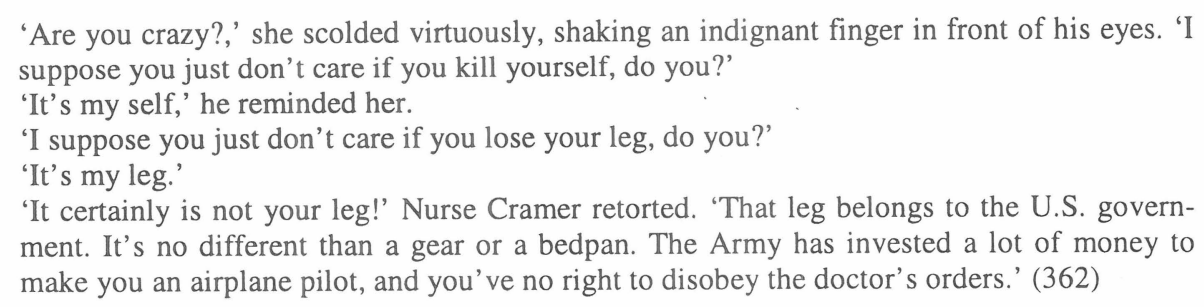

Yossarian is a misfit in that absurd war. He cannot distinguish reality and fiction any more and so, for instance, he sees Hungry Joe's nightmare about the cat on his face become true. Besides, the protagonist has an ominous name ("destined to serve as Colonel Cathcart's nemesis") that reveals that he is not suitable for Colonel Cathcart's squadron, because he is a "menacing problem" and had an "execrable, ugly name":

Yossarian - the very sight of the name made him shudder. There were so many esses in it. It just had to be subversive. It was like the word subversive itself. It was like seditious and insidious too, and like socialist, suspicious, fascist and Communist. It was an odious, alien, distasteful name, all like such clean, crisp, honest, American names as Cathcart, Peckem and Dreedle. (260-261)

Besides, his name multiplies and with the repetition, Yossarian loses his real identity:

A moment ago there had been no Yossarians in his life; now they were multiplying like hobgoblins. He tried to make himself grow calm. Yossarian was not a common name; perhaps there were not really three Yossarians but only two Yossarians, or maybe even only one Yossarian--but that really made no difference! (260)

Yossarian has qualities which are not found in the absurd world of war, such as honesty and innocence:

Milo looked at Yossarian with profound emotion. 'That's what I like about you,' he exclaimed. 'You're honest! You're the only one I know that I can really trust. That's why I wish you'd try to be of more help to me. I really was disappointed when you ran off with those two tramps in Catania yesterday.' (289)

He says that he was "born in a battlefield in a state of innocence" and thus, he shows that he cannot assimilate the experience. He is not at ease in that world and that is why he needs to escape at the end of the book.

Yossarian could become a perfect hero if the world he lives in were not "a boiling chaos in which everything was in proper order." He cannot live in that paradoxical reality or "concordia discors." There is an inverted world and he must choose between adapting to the reality situation and losing his self or escaping.

Yossarian also defies categorisation. According to some critics like Douglas Day, Yossarian can be seen as a "coward, a man who throws away all honour, sense of moral obligation and self-respect" (Nussey). Yossarian does not want to fly any more because he sees every day as "a dangerous mission against mortality." In addition, he admits he is a coward: "There was nobody else he knew who was as big a coward. Yossarian was the best man in the group at evasive action, but had no idea why" (61). 
But the protagonist's paranoia and death-hauntedness are entirely understandable because there is a war and he wants to survive. Little by little he becomes a postmodernist figure who is tired of fighting to save his country and who realises that time has come to save himself. Then for Yosssarian, it is he who is in danger and not his country and thus his mission is only to come down alive every time he flies. He does not follow the traditional values of patriarchy (represented in the army) and Colonel Cathcart regards him as a threat to the army. Yossarian "displays" a cowardly behaviour and becomes aware of the power of language to build reality, that is "catch-22." All this shows Yossarian as a non-heroic figure who in addition, is unable to kill; he refuses to kill Colonel Cathcart and McWatt and his uselessness at killing is parodied in the continuous reappearance of Nately's "unkillable" whore.

Apart from this, Yossarian is diminished to an anti-hero as a consequence of the ironic comparisons between him and other characters regarded as real heroes of war, such as Hungry Joe, whom the protagonist considers the biggest hero of the Air Force because he had flown many combat tours of duty. Harvermeyer, Milo, Danby, Pilchard and Wren are also models of good patriotic soldiers that stand out in contrast to Yossarian's philosophy of self-survival, but they are also parodied because they give absurd reasons to go on fighting in the war, such as obedience to their superiors. They represent the most clear example of the powerful manipulation of identity exerted by the army. In addition, the use of free indirect style appears in order to stress the dissolution of limits between the focalisations of the narrator and of Yossarian.

At the end, Yossarian, who understands all this absurd logic of war and shares it, discovers that war does not offer any opportunity for heroic acts (see Hungry Joe as an example). War is not a place for heroic and noble gestures because wars are caused by men and can be stopped by them. That is why Yossarian changes and instead of pretending to be a hero as he did at the beginning of the book ("to everyone he knew he wrote that he was going on a very dangerous mission," 8), he chooses to reject Colonel Cathcart and Colonel Korn's deal to become a "real" or official hero in chapter 42 and he says that he "earned that medal he got, no matter what their reasons were for giving it to me" (552).

Apart from that, the novel can also be approached as a parody of the "romance quest." Earlier critics of Heller's most successful novel such as Constance Denniston (Nagel) placed Catch-22 within the genre of the "American Romance-Parody," drawing on Northrop Frye's description of the genre in Anatomy of Criticism (1957). For Denniston, Catch22 resembled a parody of the war romance rather than a novel because the characters were idealised types rather than individuals, there were conflicts, masked identities and, more important, the structure of the novel was that of a quest. The quest is presented as a parody of the classical epic or romance (Homer's Odyssey, Virgil's Aeneid or Dante's The Divine Comedy). The ideals of the war romance are shown in reverse. Yossarian goes through the three stages of the heroic quest; first, he has a series of minor trials in the first thirty-eight chapters, where he tries to avoid death. Then he faces the major conflict in chapter 39, "The Eternal City," where he goes absent without leave to Rome and tries to find Nately's whore's kid sister. He witnesses the corruption and destruction of Rome (people being 
beaten, Aarfy murdering a girl, etc.) and it looks like a descent into hell, parodying directly the typical descent of Ulysses or Dante. Yossarian is compared to Christ then:

The night was filled with horrors, and he thought he knew how Christ must have felt as he walked through the world, like a psychiatrist through a ward full of nuts, like a victim through a prison full of thieves. What a welcome sight a leper must have been! (514)

But he is a fake Christ, unable to save Nately's whore's kid sister or to "resurrect" at the end. Finally, unlike in the romance, the hero is not elevated but mocked because he thinks he can be free rejecting Cathcart's offer and going to Sweden. But Milo's deals can reach Sweden easily and besides Sweden's coldness is associated with Snowden's death. Therefore, the situation goes back to the beginning and Yossarian is still immersed amid the forces of chaos, trying to get free.

Finally, taking into account the modern definition of parody that Linda Hutcheon gives ("repetition with difference but need not also be comic"), ${ }^{4}$ the whole of Catch-22 could act as a parody of Hemingway's A Farewell to Arms because there are many elements that are repeated and parodied, such as love, war and death. They deal with World War I and II, but in the end they end up being about the same war, fought for economic reasons. Both Hemingway and Heller insist at the beginning of their books on the fictionality of their stories:

The island of Pianosa lies in the Mediterranean sea eightmiles south of Elba. It is very smalland obviously could not accommodate all of the actions described. Like the setting of this novel, the characters, too, are fictitious. (Catch 22, 5)

None of the characters in this book is a living person, norare the units or military organisations mentioned actual units or organisations. (A Farewell to Arms, 6)

Besides, it is interesting to notice that A Farewell to Arms, which is a love story, opens with the description of war whereas Catch-22, which is in fact a book about the stupidity of all wars, has a parodic beginning as if it were a love story: "IT WAS LOVE at first sight. The first time Yossarian saw the chaplain he fell madly in love with him" (13).

A Farewell to Arms takes place in Gorizia (Italy) most of the time and Catch-22 takes place in Pianosa and in Rome. But there are many more similarities between both works: Frederick Henry and Yossarian do not like war and they have conversations with priests. They also prefer to stay at hospitals and both fall in love with nurses: Frederick Henry with Miss Catherine Barkley and Yossarian with Nurse Duckett. Yossarian's episode trying to draw a tourniquet around Snowden's thigh is also a reflection of the situation between Henry and his friend Passini:

It was Passini and when I touched him he screamed. His legs were towards me and I saw in the dark and the light that they were both smashed above the knee. One leg was gone and the other was held by tendons and part of the trouser and the stump twitched and jerked as

\footnotetext{
${ }^{4}$ Hutcheon writes in A Poetics of Postmodernism: "What I mean by "parody" here—as elsewhere in this study-is not the ridiculing imitation of the standard theories and definitions that are rooted in eighteenth-century theories of wit. The collective weight of parodic practice suggests a redefinition of parody as repetition with critical distance that allows ironic signalling of difference at the very heart of similarity" (26). Hutcheon's notion of parody also appears in Margaret A. Rose.
} 
though it were not connected. . . I I tried to get closer to Passini to try to put a tourniquet on the legs but I could not move. (54)

Henry and Yossarian are both wounded in the war and operated on. Yossarian rejects Colonel's Cathcart's offer to become a hero, as Henry does:

'You will be decorated. They want to get you the medaglia d'argento but perhaps they can get only the bronze.'

'What for?'

'Because you are gravely wounded. They say if you can prove you did any heroic act you can get the silver. Otherwise it will be the bronze. Tell me exactly what happened. Did you do any heroic act?'

'No,' I said. 'I was blown up while we were eating cheese.'

'Be serious. You must have done something heroic either before or after. Remember carefully.'

'I did not.' (61)

There are many other similarities between both works; Yossarian pretends to have jaundice and they believe he is pretending. The whores are taken away in Hemingway's story, Henry also goes absent without leave and he wants to escape to Switzerland. Therefore, Catch-22 could be regarded as a parodic imitation of Hemingway's novel but there are important differences as well: Yossarian is a soldier and Henry is in the Ambulance Corps. Then Yossarian's quest is for survival whereas Henry is a bit more distant from war and he wants Catherine's love. These differences highlight the parodic component in the novel. ${ }^{5}$ Nevertheless, the endings of both books are quite pessimistic; Yossarian is not likely to be free in Sweden and Henry loses Catherine and her baby in Switzerland.

To conclude, Catch-22 presents Yossarian as a character who is the inverse of the war hero. None the less, he could also be regarded as a hero out of the war context: he becomes a hero of language in the sense that he is the only one to see the madness around him:

Catch-22 did not exist, he was positive of that, but it made no difference. What did matter was that everyone thought it existed, and that was much worse, for there was no object or text to ridicule or refute, to accuse, criticize, attack, amend, hate, revile, spit at, rip to shreds, trample upon or burn up. (507)

This fact would make the novel a postmodernist product since the protagonist comes to realise that human beings are symbol-making animals, capable of creating multiple and contradictory "realities." Yossarian learns this after his experience in hell (Rome) and after Snowden's death, because he discovers what life means: "man was matter. . . . The spirit gone, man is garbage. That was Snowden's secret. Ripeness was all" (545). Yossarian is in a higher level than the other characters because he knows more than the others think and his paranoia is just a reflection of the absurdity around him, of the internal war within that war: "McWatt was the craziest combat man . . . because he was perfectly sane and still did not

\footnotetext{
${ }^{5}$ Stan Smith points out that traditionally, the mainline American novel had been serious, with characters that were considered "heroes" because they proved their masculinity taking risks at being defeated in the war. This can be seen in Hemingway's novel, where men go to war in order to show how powerful their country is and how male they are (my emphasis).
} 
mind the war" (80). However, Yossarian was "crazy" but "that crazy bastard may be the only sane one left," as it is said in the novel. Yossarian knows what the war means:

But Yossarian couldn't be happy, even though the Texan didn't want him to be, because outside the hospital there was still nothing funny going on. The only thing going on was a war, and no one seemed to notice but Yossarian and Dunbar. And when Yossarian tried to remind people, they drew away from him and thought he was crazy. (19)

'Doesn't he know there's a war going on?' Colonel Cathcart, still stamping back and forth, demanded morosely without looking at Yossarian. 'I'm quite sure he does,' Colonel Korn answered. 'That's probably why he refuses to fly them.' (523)

Finally, Yossarian's struggle with language seems to mirror the author himself, also struggling with language and the conventions of the novel. Then to play with the notion of Catch-22 is an escape to understand the novel. One has to "play with words" as John Barth suggested in "The Literature of Exhaustion." But the writer finds a paradox because to exist one needs a shape and that contour is provided by language. Thus parody is also metafictional (as Linda Hutcheon suggested) and there is self-reflexiveness, as it happens in post-modernist texts such as Thomas Pynchon's The Crying of Lot 49, with the Trystero system, or the game in Sam Shepard's "The Tooth of Crime." As Malcom Bradbury said:

Novelists might then celebrate an unpatterned, resistant awareness to history, system and code; they might, though, point something yet bleaker, the entry of system into the very heart of the self, rendering humanism impossible and life absurd. (157)

As a result, Cach-22 shows a new way to present the dominant theme of the modern American novel: the universe as something absurd, meaningless and chaotic. Unlike the novelists belonging to the first half of this century, Heller used the conventional novelistic methods ironically and he used absurdist techniques to deal with the absurdist content. ${ }^{6}$ Therefore, the novelist turns to parody and he addresses the burlesque not only toward the external world but also toward literature itself. Some critics like Charles B. Harris write that the reflective use of burlesque and parody shows that reality cannot be ordered through literature (the art form is not ordered either), because there are multiple realities, as a consequence of the influence of Einstein relativity and quantum physics.

Parody becomes then the best way to represent these multiple realities, because one reality gets questioned by another. Thus, at the end readers should find laughter as a response to the blackness of modern existence depicted by Heller and they should not try to look for sense in reality. ${ }^{7}$ However, the novel is quite ambiguous, because it seems to resist the idea that life is meaningless and that is why love is offered as some consolation and why the ending could be interpreted optimistically.

\footnotetext{
${ }^{6}$ Stan Smith (1981) remarks that the Shandean technique (from Sterne's Tristram Shandy, 1767) is good to deal with the plight of the self. Like in Sterne's novel, Catch-22 shows problems with time; times are divided into that of the telling and that of the events, one is chronological and the other psychological.

${ }^{7}$ These novelists look for laughter, like the French dramatists of the absurd but unlike these, as Harris points out, they cannot commit themselves totally to absurdity and resist the idea that life is meaningless (30).
} 


\section{WORKS CITED}

Barth, John. "The Literature of Exhaustion." The Atlantic 220 (August 1967): 29-34.

Bradbury, Malcolm. The Modern American Novel. Oxford: OUP, 1983.

Frye, Northrop. Anatomy of Criticism: Four Essays. Princeton, N. J.: PUP, 1957.

Harris, Charles B. Contemporary American Novelists of the Absurd. New Haven, Conn.: College and UP, 1971.

Heller, Joseph. Catch-22. [1955] London: Everyman's Library, 1995.

Hemingway, Ernest. A Farewell to Arms. [1929] London: Heinemann Educational Books, 1978.

Hilfer, A. American Fiction Since 1940. New York: Longman, 1992.

Hutcheon, Linda. A Poetics of Postmodernism: History, Theory, Fiction. [1988] New York: Routledge, 1989.

Lehmann, Paul. Die Parodie im Mittelalter. [1963] In Joseph A Dane, Parody: Critical Concepts Versus Literary Practices: Aristophanes to Sterne. New York: U of Oklahoma P, 1988 .

Nagel, James. Critical Essays on Catch-22. New York: Dickenson Seminar Series in Criticism, 1974.

Nussey, Kevin. "War and comedy in Joseph Heller's Catch-22 and Kurt Vonnegut's Slaughterhouse Five." UEA Thesis, M.A., 1983: Ch. IV.1.

Rose, Margaret A.. Parody: Ancient, Modern, and Post-modern. Cambridge: CUP, 1993.

Smith, Stan. A Sadly Contracted Hero: The Comic Self in Post-war American Fiction. South Shields: Peterson Printers. British Association for American Studies, Pamphlet 5, 1981.

Tanner, Tonny. City of Words: American Fiction 1950-1970. London: Jonathan Cape Ltd., 1971. 
